\title{
Identifikasi Jenis Bambu Berdasarkan Tekstur Daun dengan Metode Gray Level Co-Occurrence Matrix dan Gray Level Run Length Matrix
}

\author{
Identification of Bamboo Species Based on Leaf Texture using Gray Level \\ Co-Occurrence Matrix and Gray Level Run Length Matrix \\ Endina Putri Purwandari ${ }^{*}$, Rachmi Ulizah Hasibuan, Desi Andreswari \\ Program Studi Infomatika, Fakultas Teknik, Universitas Bengkulu \\ Jl. WR. Supratman Kandang Limun, Bengkulu, Indonesia 38371
}

\begin{abstract}
Cara sitasi: E. P. Purwandari, R. U. Hasibuan, and D. Andreswari, "Identifikasi Jenis Bambu Berdasarkan Tekstur Daun dengan Metode Gray Level Co-Occurrence Matrix dan Gray Level Run Length Matrix,” Jurnal Teknologi dan Sistem Komputer, vol. 6, no. 4, pp. 146-151, Oct. 2018. doi: 10.14710/jtsiskom.6.4.2018.146-151, [Online].
\end{abstract}

\begin{abstract}
Bamboo species can be identified from the bamboo leaf images. This study conducted the identification of bamboo species based on leaf texture using Gray Level Co-occurrence Matrix (GLCM) and Gray Level Run Length Matrix (GLRLM) for texture feature extraction, and Euclidean distance for measure the image distance. This study used the images of bamboo species in Bengkulu province, that are bambusa Vulgaris Var Vulgaris, bambusa Multiplex, bambusa Vulgaris Var Striata, Gigantochloa Robusta, Gigantochloa Schortrchinii, Gigantochloa Serik, Schizostachyum Brachycladum, and Dendrocalamus Asper. The bamboo application was built using Matlab. The accuracy of the application was $100 \%$ for bamboo leaf test images captured using a smartphone camera and $81.25 \%$ for test images downloaded from the Internet.
\end{abstract}

Keywords - bamboo identification; bamboo leaf; grey level co-occurrence matrix; gray level run length matrix

Abstrak - Identifikasi jenis bambu dapat dilakukan dengan menggunakan citra daun bambu. Penelitian ini bertujuan membangun aplikasi identifikasi jenis bambu berdasarkan tekstur daun berbasis konten citra dengan menggunakan metode Gray Level Cooccurrence Matrix (GLCM) dan Gray Level Run Length Matrix (GLRLM) untuk ekstraksi fitur tekstur serta metode Euclidean distance untuk menghitung jarak kemiripan citra uji dengan citra latih. Objek penelitian ini adalah citra daun bambu di Bengkulu yaitu bambu Ampel (Bambusa Vulgaris Var. Vulgaris), bambu Cina (Bambusa Multiplex), bambu Kuning (Bambusa Vulgaris Var. Striata), bambu Kemayan/Mayan (Gigantochloa Robusta), bambu Kapal (Gigantochloa Schortrchinii), bambu Serik/Sri (Gigantochloa Serik), bambu Gading (Schizostachyum Brachycladum), dan bambu Betung (Dendrocalamus Asper). Aplikasi identifikasi ini dibangun menggunakan Matlab. Akurasi aplikasi ini adalah

\footnotetext{
${ }^{*}$ Penulis korespondensi (Endina Putri Purwandari)

Email: endinaputri@unib.ac.id
}

$100 \%$ untuk citra uji daun bambu yang diambil menggunakan smartphone dan 81,25 \% untuk citra uji yang diunduh dari Internet.

Kata Kunci - identifikasi bambu; daun bambu; gray level co-occurrence matrix; gray level run length matrix

\section{Pendahuluan}

Indonesia adalah negara tropis yang memiliki keanekaragaman tumbuhan tinggi, termasuk bambu, yang banyak tumbuh subur dan memiliki banyak jenis dan manfaat yang tidak banyak diketahui. Kondisi ini mempersulit proses identifikasi. Spesies bambu di Indonesia diperkirakan sekitar 159 spesies dari total 1.250 spesies di seluruh dunia [1]. Bambu dapat ditemukan di dataran rendah, pegunungan, tempattempat terbuka dan daerah bebas dari genangan air. Ciriciri umum dari bambu yaitu hidup merumpun, batang bulat, berlubang di tengah dan beruas-ruas, percabangan kompleks, setiap daun bertangkai, serta mempunyai ruas dan buku [2].

Identifikasi spesies bambu dapat dilakukan melalui daunnya menggunakan fitur tekstur daun. Fitur tekstur daun yang dapat digunakan untuk menentukan ciri khas tanaman, termasuk bambu, adalah antara lain licin, halus, kasar, dan keteraturan susunan struktural piksel [3]. Proses analisa tekstur daun dapat dilakukan dengan cepat dengan memanfaatkan teknik pengolahan citra digital [4], [5]. Beragam teknik pengolahan citra digital telah dikembangkan untuk identifikasi jenis tanaman. Teknik ini melakukan ekstraksi fitur tekstur dengan akurasi yang baik, di antaranya dengan Gray Level Cooccurence Matrix (GLCM) untuk menentukan matriks co-occurence yang menunjukkan hubungan pasial antara level keabuan dalam citra tekstur [6]-[10] dan Gray Level Run Length Matrix (GLRLM) yang mampu membedakan citra halus dan citra kasar [11], [12].

Identifikasi menggunakan GLCM dan GLRLM mempunyai akurasi yang memadai. Tiap objek mempunyai ciri yang membedakannya dengan objek lain, misalnya dalam identifikasi citra daun tanaman obat herbal [6], citra kayu [7], daun tebu [8], kesegaran 


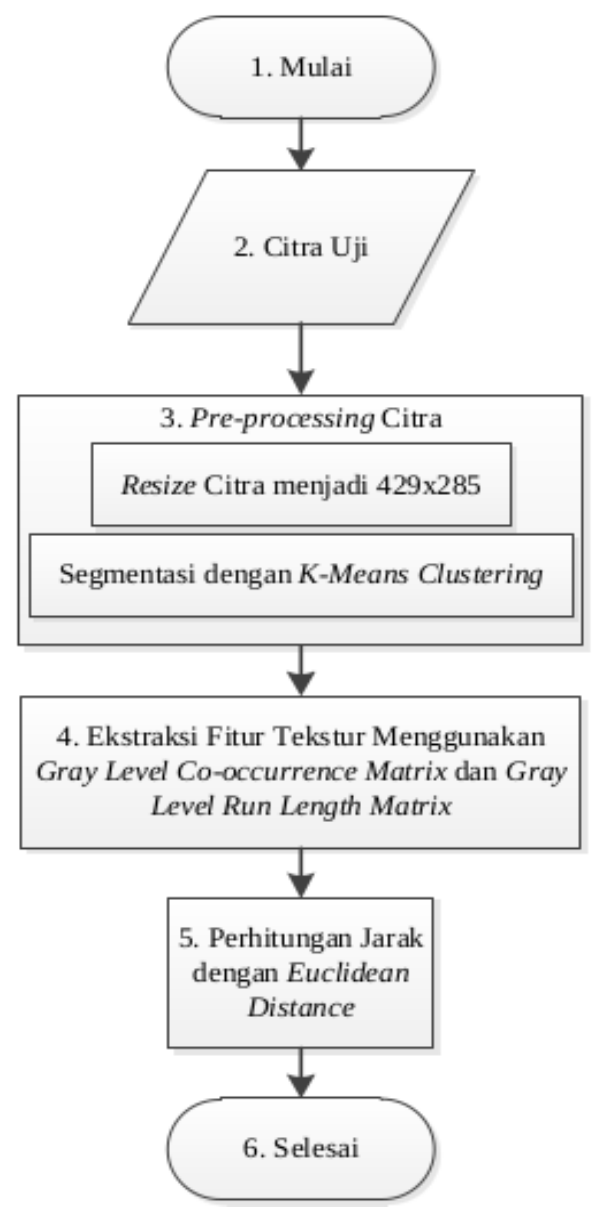

Gambar 1. Diagram alur identifikasi jenis bambu

sapi [9], prasasti logam [12] dan pengenalan buah [13] Identifikasi ragam jenis bambu terutama yang tumbuh di Indonesia belum banyak yang mengkaji. Penelitian ini mengembangkan teknik identifikasi jenis bambu berdasarkan tekstur daunnya menggunakan GLCM dan GLRLM. Perhitungan jarak antara citra latih dan citra citra uji dilakukan menggunakan jarak Euclidean.

\section{Metode Penelitian}

Proses identifikasi jenis bambu berdasarkan tekstur daun ini terdiri dari empat tahap utama, yaitu akuisisi citra digital, pra-pengolahan citra, ekstraksi fitur tekstur, perhitungan jarak dengan Euclidean distance (Gambar 1). Bambu yang menjadi objek dalam penelitian ini sebanyak 8 spesies bambu (Gambar 2), yaitu bambu Ampel (Bambusa Vulgaris Var. Vulgaris), bambu Cina (Bambusa Multiplex), bambu Kuing (Bambusa Vulgaris Var. Striata), bambu Kemayan/Mayan (Gigantochloa Robusta), bambu Kapal (Gigantochloa Schortrchinii), bambu Serik/Sri (Gigantochloa Serik), bambu Gading (Schizostachyum Brachycladum), dan bambu Betung (Dendrocalamus Asper). Pengembangan aplikasi identifikasi jenis bambu ini dilakukan menggunakan Matlab.

Akuisisi citra digital dilakukan dengan smartphone iPhone 5s dan resolusi kamera sebesar 8 Megapixels

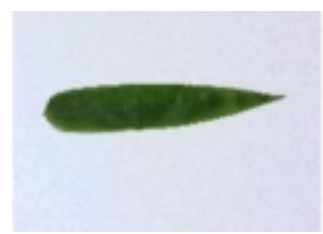

(a)

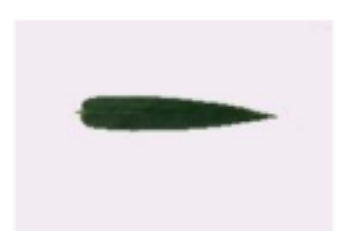

(c)

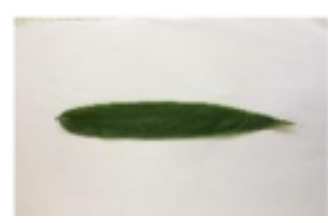

(e)

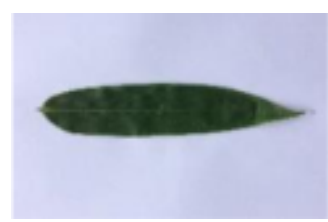

(g)

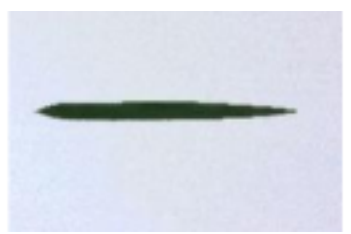

(b)

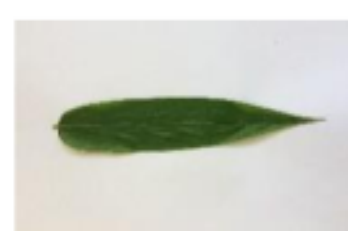

(d)

(f)

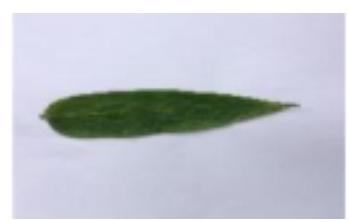

(h)

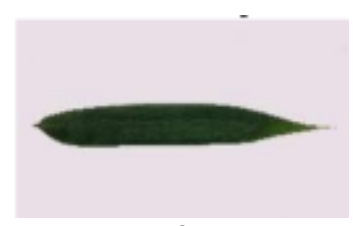

Gambar 2. Citra daun dari 8 jenis bambu: a) Ampel, b) Cina, c) Kuning, d) Mayan, e) Kapal, f) Serik/Sri, g) Gading, dan h) Betung

dengan jarak $20 \mathrm{~cm}$ terhadap obyek. Tahap prapengolahan atau pre-processing terdiri dari tahap konversi nilai RGB citra menjadi citra abu-abu atau grayscale, mengubah ukuran citra citra menjadi 429x285 piksel, dan melakukan proses pemisahan obyek daun dengan latar belakang obyek (segmentasi) dengan K-Means clustering.

Tahap analisis ekstraksi fitur tekstur pada identifikasi jenis bambu ini menggunakan algoritma GLCM dan GLRLM. Citra diolah menggunakan citra hasil pra-pengolahan citra. Pembentukan matriks kookurensi dilakukan dengan cara mencari frekuensi kemunculan piksel dengan masing-masing tetangganya. Matrik ini berukuran $L \times L$ dengan $L$ menyatakan banyaknya tingkat keabuan dari elemen-elemen $P(x, y)$ yang merupakan distribusi probabilitas bersama dari pasangan piksel dengan tingkat keabuan $x$ yang berlokasi di koordinat $(j, k)$ dan $y$ yang berlokasi di koordinat $(m, n)$. Koordinat pasangan piksel tersebut berjarak $r$ piksel dengan sudut orientasi $\theta$ derajat. Orientasi dibentuk dalam empat arah sudut dengan interval sudut $45^{\circ}$, yaitu $0^{\circ}, 90^{\circ}$, dan $135^{\circ}$, sedangkan jarak antar piksel sebesar 1 piksel.

Proses ekstraksi vektor fitur tekstur menggunakan 4 fitur GLCM, yaitu energy E (Persamaan 1), contrast I (Persamaan 2), correlation $C$ (Persamaan 3), dan homogenity $H$ (Persamaan 4) serta 5 fitur GLRLM, yaitu 


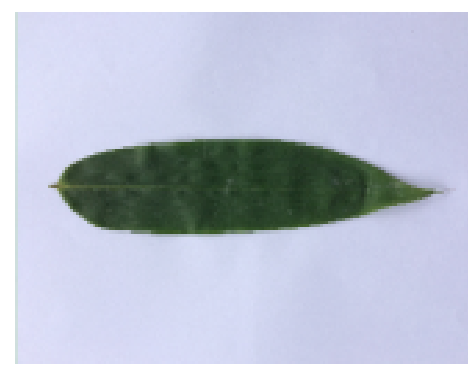

(a)

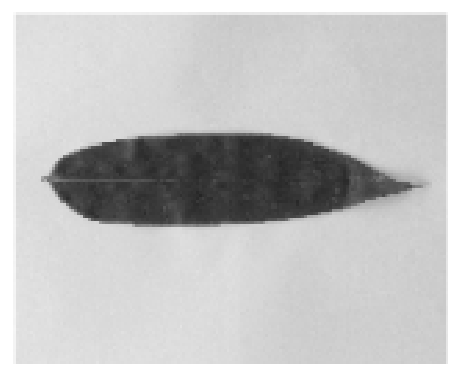

(b)

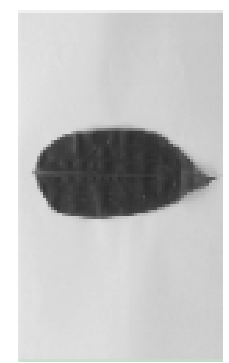

(c)

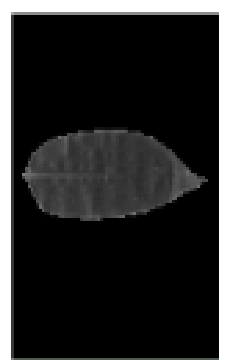

(d)

Gambar 3. Proses pra-pengolahan citra: a) citra RGB, b) citra keabuan, c) citra hasil resize, dan d) hasil segmentasi dengan K-means clustering

short run emphasis / SRE (Persamaan 5), long run emphasis / LRE (Persaman 6), gray level uniformity / GLE (Persamaan 7), run length uniformity / RLU (Persamaan 8), dan run percentage / RPC (Persamaan 9). Parameter $\sigma$ menyatakan variansi, $\mu$ rata-rata, $P(i, j)$ nilai pasangan piksel $i$ dan $j, M$ jumlah derajat keabuan pada sebuah citra, $N$ jumlah pikses berurutan pada sebuah citra, $s$ jumlah total nilai run yang dihasilkan pada arah tertentu dan $n$ jumlah baris kali jumlah kolom. Analisis tekstur metode GLRLM ini digunakan untuk membedakan citra halus dan citra kasar. Dari proses ekstraksi fitur tersebut diperoleh 9 nilai vektor yang mewakili fitur-fitur yang digunakan [4], [5].

$$
\begin{gathered}
E=\sum_{x} \sum_{y} P^{2}(x, y) \\
I=\sum \sum_{C=}(x-y)^{2} P(x, y) \\
H=\sum_{x} \sum_{y} \frac{1}{1+(x-y)^{2}} P(x, y) \\
S R E=\sum_{i=1}^{M} \sum_{j=1}^{N} \frac{P(i, j) / s}{j^{2}} \\
L R E=\sum_{i=1}^{M} \sum_{j=1}^{N} \frac{j^{2} P(i, j)}{S} \\
G L U=\sum_{i=1}^{M} \sum_{j=1}^{N} \frac{P(i, j)^{2}}{S} \\
R L U=\sum_{i=1}^{N} \sum_{j=1}^{M} \frac{P(i, j)^{2}}{S} \\
R P C=\sum_{i=1}^{M} \sum_{j=1}^{N} \frac{P(i, j)}{n}
\end{gathered}
$$

Metode klasifikasi tetangga terdekatnya dilakukan dengan menghitung jarak antara dua buah objek menggunakan jarak Euclidean. Tahap perhitungan jarak dengan menggunakan algoritma jarak Euclidean, yaitu selisih antara obyek citra latih dan citra uji pada sistem (Persamaan 10). Parameter $j_{\left(v_{1}, v_{2}\right)}$ menyatakan jarak Euclidean, $v_{1}$ pola citra latih, $v_{2}$ pola citra uji, dan $N$ jumlah data latih.

$$
j_{\left(v_{1}, v_{2}\right)}=\sqrt{\sum_{k=1}^{N}\left(v_{1}(k)-v_{2}(k)\right)^{2}}
$$

Tahap pengujian kelayakan sistem dilakukan dengan mengukur akurasi atau keefektifan sistem dan hasil identifikasi daun bambu menggunakan Persamaan 11. Pengujian dilakukan dengan menggunakan 8 citra uji yang diambil dari telepon cerdas iPhone $5 \mathrm{~s} \quad 8$ Megapiksel dan 16 citra uji dari Internet.

$$
\text { akurasi }=\frac{\text { jumlahdatauji benar }}{\text { jumlahdatauji }} \times 100 \%
$$

\section{Hasil dan PeMbahasan}

Proses pra-pengolahan citra meliputi konversi nilai RGB citra daun bambu menjadi citra abu-abu, pengubahan ukuran citra keabuan menjadi 429x285 piksel, pemisahan obyek daun dengan latar belakang obyek (segmentasi) dengan K-Means clustering (Gambar 3). Citra hasil pra-pengolahan tersebut menjadi masukan dalam proses ekstraksi fitur tekstur daun.

Proses ekstraksi fitur tekstur citra menggunakan algoritma GLCM dan GLRLM mempunyai 4 proses, yaitu pengambilan nilai matriks dari citra hasil prapengolahan, inisialisasi sebuah matriks baru, pembentukan matriks kookurensi dengan sudut $45^{\circ}$, yaitu $0^{\circ}, 90^{\circ}$, dan $135^{\circ}$ dengan jarak menggunakan 1 piksel. Gambar 4 menunjukkan hasil ekstraksi fitur tekstur dengan algoritma GLCM dan GLRLM beserta 9 nilai cirinya ( $E, I, C, H, S R E, L R E, G L U, L R U$, dan $R P C$ ) dan informasi jenis bambu. Nilai ciri daun bambu tersebut diperoleh dengan menggunakan Persamaan 1 sampai Persamaan 9.

Secara keseluruhan, pengujian identifikasi jenis bambu dengan algoritma GLCM dan GLRLM dilakukan dengan menggunakan 2 tipe citra uji. Citra uji pertama menggunakan 8 citra uji yang diambil menggunakan telepon cerdas iPhone 5s 8 Megapiksel dari jarak $20 \mathrm{~cm}$ (Gambar 5) dan tipe kedua mengunakan 16 citra uji yang diambil dari Internet (Gambar 6). Citra ciri tekstur daun diperoleh dari hasil pra-pengolahan. Citra-citra uji tersebut mewakili 8 jenis bambu yang diteliti.

Dalam pengujian identifikasi terhadap 8 citra uji yang diambil menggunakan telepon cerdas, semua citra dapat teridentifikasi dengan benar. Berdasarkan 8 kali 


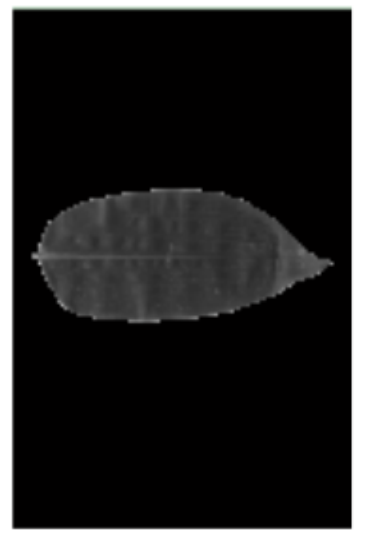

\begin{tabular}{|c|c|c|}
\hline & Nama Ciri & Nilai Ciri \\
\hline 1 & ENERGY & 0.70572 \\
\hline 2 & CONTRAST & 37.3511 \\
\hline 3 & HOMOGENEITY & 0.91222 \\
\hline 4 & CORRELATION & 0.95995 \\
\hline 5 & SRE & $3.4512 \mathrm{e}-06$ \\
\hline 6 & LRE & 0.0023131 \\
\hline 7 & GLU & $2.8962 \mathrm{e}-06$ \\
\hline 8 & RLU & $2.8962 \mathrm{e}-06$ \\
\hline 9 & RPC & $1.5259 \mathrm{e}-05$ \\
\hline
\end{tabular}

(a) (b)

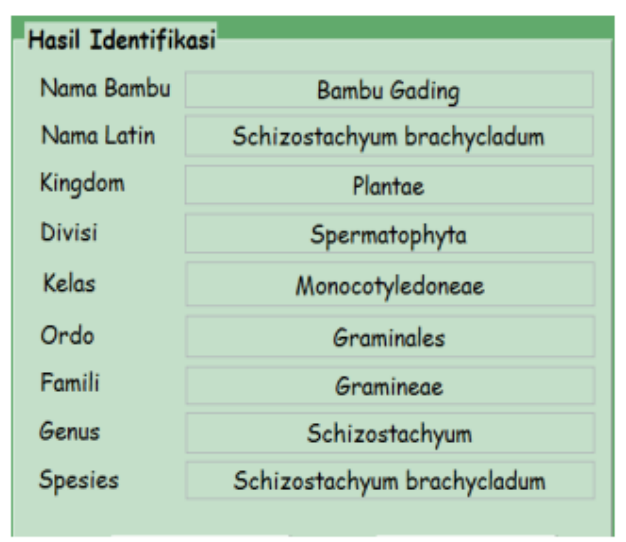

(c)

Gambar 4. Ekstraksi fitur tekstur: a) citra ekstraksi, b) nilai fitur, dan c) informasi hasil identifikasi jenis bambu

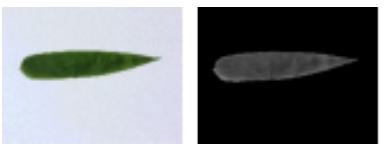

(a)

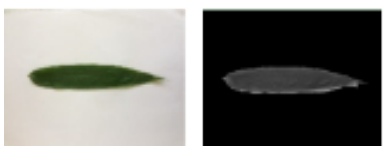

(e)

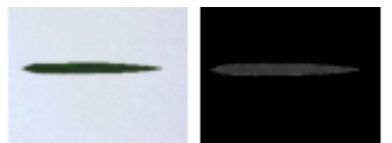

(b)

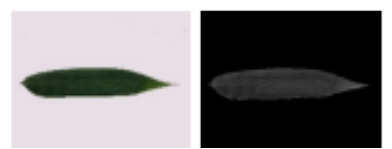

(f)

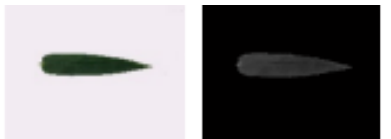

(c)

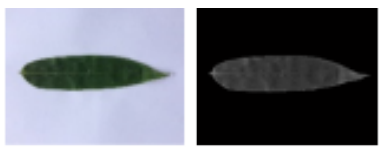

(g)

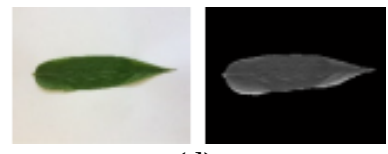

(d)

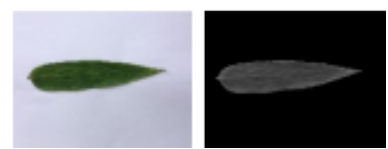

(h)

Gambar 5. Pasangan citra uji daun bambu dari kamera telepon cerdas dan ciri teksturnya: a) Ampel, b) Cina,

c) Kuning, d) Mayan/Kemayan, e) Kapal, f) Serik/Sri, g) Gading, dan h) Betung

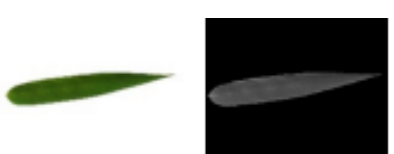

(a)

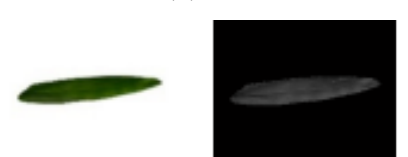

(e)

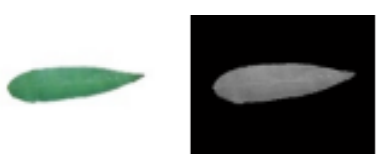

(i)

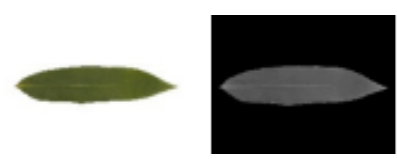

(m)

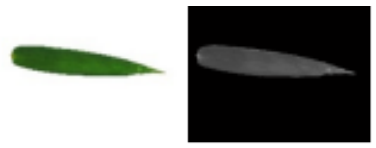

(b)

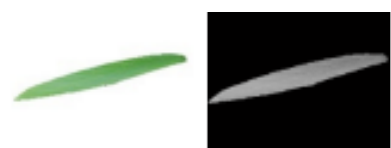

(f)

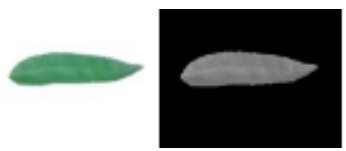

(j)

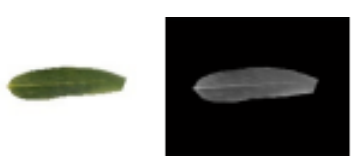

(n)

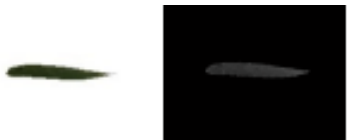

(c)

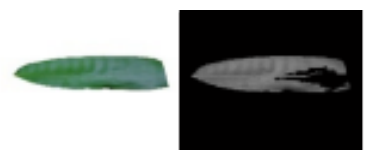

(g)

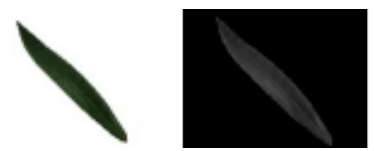

(k)

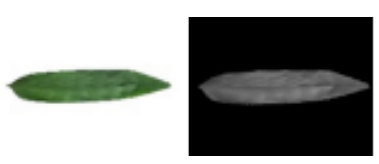

(o)

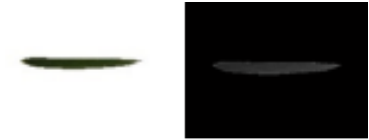

(d)

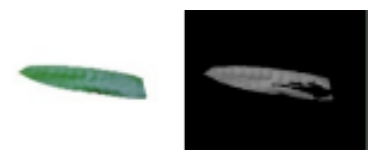

(h)

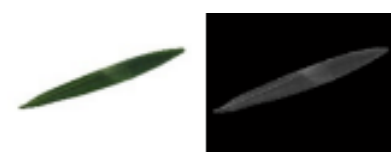

(l)

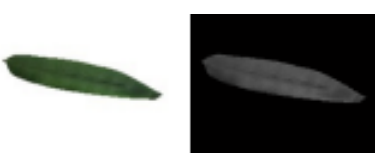

(p)

Gambar 6. Pasangan citra uji daun bambu dari sumber Internet dan ciri teksturnya: a,b) Ampel, c,d) Cina, e,f) Kuning, g,h) Mayan/Kemayan, i,j) Kapal, k,l) Serik/Sri, m,n) Gading, dan o,p) Betung

identifikasi tidak ada kegagalan atau kesalahan identifikasi. Akurasi yang diperoleh sesuai dengan Persamaan 11 adalah 100\%. Hal ini dikarenakan citra yang diambil melalui telepon cerdas memiliki keadaan yang sama dengan citra latih, seperti kecerahan, background, dan ketajaman citra. Kombinasi dari metode GLCM dan GLRLM menghasilkan ketepatan yang tinggi pada hasil identifikasi. Aplikasi ini menampilkan hasil identifikasi berupa citra yang memiliki nilai-nilai ekstraksi ciri paling mirip dengan 
Tabel 1. Hasil pengujian identifikasi citra bambu yang diambil menggunakan telepon cerdas beserta jaraknya

\begin{tabular}{|c|c|c|}
\hline Citra Uji & $\begin{array}{c}\text { Jarak } \\
\text { Euclidean }\end{array}$ & Ket. \\
\hline 1. Bambu Ampel & 7,2648 & $\begin{array}{l}\text { Deteksi } \\
\text { berhasil }\end{array}$ \\
\hline 2. Bambu Cina & 12,1821 & $\begin{array}{l}\text { Deteksi } \\
\text { berhasil }\end{array}$ \\
\hline 3. Bambu Kuning & 7,7591 & $\begin{array}{l}\text { Deteksi } \\
\text { berhasil }\end{array}$ \\
\hline 4. Bambu Mayan/Kemayan & 27,6888 & $\begin{array}{l}\text { Deteksi } \\
\text { berhasil }\end{array}$ \\
\hline 5. Bambu Kapal & 13,5912 & $\begin{array}{l}\text { Deteksi } \\
\text { berhasil }\end{array}$ \\
\hline 6. Bambu Serik/Sri & 6,4926 & $\begin{array}{l}\text { Deteksi } \\
\text { berhasil }\end{array}$ \\
\hline 7. Bambu Gading & 10,3806 & $\begin{array}{l}\text { Deteksi } \\
\text { berhasil }\end{array}$ \\
\hline 8. Bambu Betung & 0,6398 & $\begin{array}{l}\text { Deteksi } \\
\text { berhasil }\end{array}$ \\
\hline
\end{tabular}

citra uji yang dimasukkan. Jarak Euclidean tiap citra uji yang diperoleh menggunakan Persamaan 10 untuk 9 ciri GLCM dan GLRLM dinyatakan dalam Tabel 1. Jarak ini menunjukkan bahwa antara citra latih dan citra uji mempunyai kedekatan berdasarkan nilai cirinya.

Hasil pengujian 16 citra uji yang diambil dari Internet hanya ada 13 citra yang dapat teridentifikasi dengan benar (Tabel 2) atau tingkat akurasi sistem untuk identifikasi citra dari Internet berdasarkan Persamaan 11 adalah 81,25\%. Kegagalan terjadi terhadap citra uji keenam, kesebelas, dan keduabelas atau di citra bambu Kuning dan bambu Serik/Sri. Hal ini disebabkan citra yang diambil dari Internet memiliki keadaan yang berbeda dengan citra latih, seperti kecerahan, jarak pengambilan citra dan kualitas citra. Metode GLRLM tidak efektif dalam membedakan citra halus dan citra kasar pada citra masukan. Selain itu, terdapat perbedaan nilai jarak Euclidean yang terlalu besar sehingga tidak teridentifikasi jenis bambu tersebut terhadap citra latih, yaitu berturut-turut sebesar 44,4401, 47,9252, dan 42,8162 piksel (Tabel 2).

Keberhasilan pengujian pada sistem dengan menggunakan citra uji yang diambil dari Internet mengalami 3 kesalahan atau kegagalan dikarenakan nilai kekasaran dan kehalusan dari citra Internet yang mempengaruhi nilai ekstraksi fitur GLRLM, dan besarnya nilai kontras dari citra yang mempengaruhi nilai ekstraksi fitur GLCM. Pengujian untuk citra yang diambil menggunakan kamera telepon cerdas, menunjukkan bahwa kombinasi GLCM dan GLRLM menghasilkan akurasi deteksi yang lebih tinggi (100\%) daripada [6]-[9] yang menggunakan GLCM untuk citra obat herbal, citra kayu, penyakit daun tebu, dan kesegaran daging sapi, dan dengan [12] yang menggunakan GLRLM untuk citra prasasti. Kombinasi fitur GLCM dan GLRLM juga meminimalkan kesalahan dalam identifikasi citra Internet sehingga
Tabel 2. Hasil pengujian identifikasi citra bambu yang diambil dari Internet beserta jaraknya

\begin{tabular}{|c|c|c|}
\hline Citra Uji & $\begin{array}{c}\text { Jarak } \\
\text { Euclidean }\end{array}$ & Ket. \\
\hline 1. Bambu Ampel & 4,0364 & $\begin{array}{l}\text { Deteksi } \\
\text { berhasil }\end{array}$ \\
\hline 2. Bambu Ampe & 5,5226 & $\begin{array}{l}\text { Deteksi } \\
\text { berhasil }\end{array}$ \\
\hline 3. Bambu Cina & 14,416 & $\begin{array}{l}\text { Deteksi } \\
\text { berhasil }\end{array}$ \\
\hline 4. Bambu Cina & 13,3858 & $\begin{array}{l}\text { Deteksi } \\
\text { berhasil }\end{array}$ \\
\hline 5. Bambu Kuning & 7,8009 & $\begin{array}{l}\text { Deteksi } \\
\text { berhasil }\end{array}$ \\
\hline 6. Bambu Kuning & 44,4401 & $\begin{array}{c}\text { Tidak } \\
\text { terdeteksi }\end{array}$ \\
\hline 7. Bambu Mayan/Kemayan & 32,4935 & $\begin{array}{l}\text { Deteksi } \\
\text { berhasil }\end{array}$ \\
\hline 8. Bambu Mayan/Kemayan & 28,7442 & $\begin{array}{l}\text { Deteksi } \\
\text { berhasil }\end{array}$ \\
\hline 9. Bambu Kapal & 11,4435 & $\begin{array}{l}\text { Deteksi } \\
\text { berhasil }\end{array}$ \\
\hline 10. Bambu Kapal & 18,1429 & $\begin{array}{l}\text { Deteksi } \\
\text { berhasil }\end{array}$ \\
\hline 11. Bambu Serik/Sri & 47,9252 & $\begin{array}{c}\text { Tidak } \\
\text { terdeteksi }\end{array}$ \\
\hline 12. Bambu Serik/Sri & 42,8162 & $\begin{array}{c}\text { Tidak } \\
\text { terdeteksi }\end{array}$ \\
\hline 13. Bambu Gading & 10,7214 & $\begin{array}{l}\text { Deteksi } \\
\text { berhasil }\end{array}$ \\
\hline 14. Bambu Gading & 9,5502 & $\begin{array}{l}\text { Deteksi } \\
\text { berhasil }\end{array}$ \\
\hline 15. Bambu Betung & 1,5348 & $\begin{array}{l}\text { Deteksi } \\
\text { berhasil }\end{array}$ \\
\hline 16. Bambu Betung & 2,1005 & $\begin{array}{l}\text { Deteksi } \\
\text { berhasil }\end{array}$ \\
\hline
\end{tabular}

mampu mendapatkan akurasi yang memadai, yaitu sebesar $81,25 \%$.

\section{KESIMPULAN}

Metode GLCM dan GLRLM dapat diterapkan untuk identifikasi 8 jenis bambu yang tumbuh di Bengkulu dengan akurasi yang tinggi, yaitu 100\% untuk citra uji yang diambil dari telepon cerdas dan 81,25\% untuk citra uji yang diambil dari Internet.

\section{UCAPAN TERIMA KASIH}

Terima kasih disampaikan kepada Universitas Bengkulu atas dukungannya terhadap penelitian ini.

\section{DAfTAR PUStaka}

[1] E. P. Purwandari, A. P. Yani, R. Sugraha, K. Anggriani, and E. W. Winarni, "Online Expert Systems for Bamboo Identification Using Case Based Reasoning," International Journal of 
Electrical and Computer Engineering, vol. 7, no. 5, pp. 2776-2772, 2017.

[2] A. P. Yani, "Keanekaragaman Dan Populasi Bambu Di Desa Talang Pauh Bengkulu Tengah,” Exacta, vol. X, no. 1, pp. 61-70, 2012.

[3] A. Rakhmadi, N. Suciati, and A. Navastara, "Fitur Berbasis Fraktal dari Koefisien Wavelet untuk Klasifikasi Citra Daun,” JUTI: Jurnal Ilmiah Teknologi Informasi, vol. 15, no. 2, pp. 238-247, 2017.

[4] E. P. Purwandari, Konsep dan Teori Pengolahan Citra Digital. Bengkulu: UNIB Press, Universitas Bengkulu, 2018.

[5] A. Kadir and A. Susanto, Teori dan Aplikasi Pengolahan Citra Digital. Yogyakarta: Penerbit Andi, 2013.

[6] F. Shofrotun, T. Sutojo, D. R. Ignatius, and M. Setiadi, "Identifikasi Tumbuhan Obat Herbal Berdasarkan Citra Daun Menggunakan Algoritma Gray Level Co-occurence Matrix dan K-Nearest Neighbor," Jurnal Teknologi dan Sistem Komputer, vol. 6, no. 2, pp. 51-56, 2018.

[7] S. Saifudin and A. Fadlil, "Sistem Identifikasi Citra Kayu Berdasarkan Tekstur Menggunakan Gray Level Coocurrence Matrix (GLCM) Dengan Klasifikasi Jarak Euclidean," Sinergi: Jurnal Teknik Mercu Buana, vol. 19, no. 3, pp. 181-186, 2015.
[8] R. K. Dewi and R. H. Ginardi, "Identifikasi Penyakit pada Daun Tebu dengan Gray Level CoOccurrence Matrix dan Color Moments," Jurnal Teknologi Informasi dan Ilmu Komputer, vol. 1, no. 2, pp. 70-77, 2014.

[9] R. A. Asmara, D. Puspitasari, S. Romlah, Q. Hasanah, and R. Romario. "Identifikasi Kesegaran Daging Sapi Berdasarkan Citranya dengan Ekstraksi Fitur Warna dan Teksturnya Menggunakan Metode Gray Level Cooccurrence Matrix," SENTIA, vol. 9, pp. 89-94,2017.

[10] A. Halim, Hardy, and Mytosin, "Aplikasi Image Retrieval dengan Histogram Warna dan Multiscale GLCM,” JSM (Jurnal SIFO Mikroskil), vol. 16, no. 1, pp. 41-50, 2015.

[11] I. Santoso, Y. Christyono, and M. Indriani, "Kinerja Pengenalan Citra Tekstur Menggunakan Analisis Tekstur Metode Run Length,” in Seminar Nasional Aplikasi Teknologi Informasi, Jun 16, 2007, Yogyakarta, Indonesia, pp. 19-25.

[12] I. Setiawan, K. Dedi, S. T. Rasmana, and M. C. Wibowo. "Analisis Fitur Citra Prasasti Logam Menggunakan Metode Gray Level Run Length Matriks (GLRLM)," Journal JCONES, vol. 4, no. 1, pp. 22-30, 2015.

[13] B. Aditya, A. Hidayatno, and A. A. Zahra, "Sistem Pengenalan Buah Menggunakan Metode Discrete Cosine Transform dan Euclidean Distance,” Transient, vol. 3, no. 2, pp. 134-138, 2014. 